\title{
Returning to Youth and Nature - The Catcher in the Rye in Ecocriticism
}

\author{
Cui Wang \\ Dezhou University, Dezhou 253023, China \\ E-mail: pengfei5188@sina.com \\ Xiaofen Zhang \\ Dezhou University, Dezhou 253023, China \\ Email: dzzxf369@163.com
}

\begin{abstract}
J.D. Salinger's The Catcher in the Rye depicted a young man Holden Caulfield who spurned the adults' world and was eager to be a catcher in the rye, which showed his passion for returning to youth and nature and his thoughts of ecophilosophy, Which is of eternal significance.
\end{abstract}

Index Terms - Salinger, The Catcher in the Rye, ecocriticism, return, youth, nature.

\section{INTRODUCTION}

"Do you happen to know where they go, the ducks, when it gets all frozen over?" This is a question repeatedly occurring in The catcher in the rye. It shows the hero's nervousness in his current situation and puzzle on the future, which is also shared by the author and the whole postwar generation. J.D. Salinger is not a prolific writer. Apart from several short stories, The Catcher in the Rye is his only full-length novel that has been published. Yet due to this controversial novel, he gained remarkable reputation in the fifties and became popular in the country. So far, J.D. Salinger has been recognized by many critics and readers as one of the most popular and influential fiction writers in the contemporary American literary history.

The catcher in the rye successfully portrays an emotionally disturbed sixteen-year-old boy from a middle--class family. With a first--person narration, the protagonist introduces his own three-day experience in New York after he was expelled from school for his poor study. During his two days' vagrancy, he encounters various people, e.g. nuns, a prostitute, his younger sister, his former teachers etc. He talks with these people, discloses the phoniness of the adults and appreciates the innocence of the children. Holden talks a lot, but he is not able to really communicate with the outside world. The story ends in a mental institution where Holden accounts his own story to the readers. The story has enjoyed a readership that has transcended the boundaries of age, education, and culture. Its reputed charm has moved a variety of critics. More than 30 years after its publication, it has still been considered as one of the two "modern classics" in contemporary American literature. And it stands out to be Salinger's only novel that sets up his fame to this day as well. In the story Holden want to be "the catcher in the rye", which showed his passion for returning to youth and nature and his thoughts of ecophilosophy. It had great influence on the literature and culture in America after the Second World War.

\section{ECOCRITICISM}

In the Ecocriticism Reader, Cheryll Glotfelty defines ecocriticism as "the study of the relationship between literature and the physical environment". There is a certain appeal in the simplicity and inclusiveness of this definition. Yet it begs the question: How exactly is this new perspective? Or does ecocriticism merely put old wine in a new bottle? In The Environmental Imagination, Lawrence Buell defines ecocriticism as "[a]study of the relationship between literature and the environment conducted in a spirit of commitment to environmentalist praxis"(430). Buells' definition is valid, as far as it goes, and it indicates that ecocriticism is not just a means of analyzing nature in literature but implies a more ecocentric world-view, which extends the environmental ethics. Under the guidance of this world-view, human beings may broaden their conception of global community to include nonhuman life forms and the physical environment. Ecocriticism would advocate reconsidering how the narrowness of our traditional idea about the natural world has limited our ability to realize a sustainable society. The ecocritics aim to examine the role literary work plays in the complex relationships between humankind and environment, between mind and world, between thinking, being and dwelling. In endeavoring to reconnect culture with nature, ecocritics should resist the illusion of totally returning to the good old days when human and nature lived in complete harmony. Rather, they should attempt to make a change in consciousness, seeking in all sorts of creative literary works for a different way of viewing nature which may save human from the current ecological crises. As what Mazel said in his book A Century of Early Ecocriticism, "No matter 
how it is defined, ecocriticism seems less a singular approach or method than a constellation of approaches, having little more in common than a shared concern with the environment".(2001:2)

Ecological consciousness was first advocated by Aldo Leopold (1887-1948) in his posthumous book, A Sand County Almanac, in 1949. Aldo Leopold emphasizes that we should be striving for harmony with the land and admitting at the outset that the thing we need must grow from within. Once humanity looks at organisms as individuals, having intrinsic value in them, we are more likely to show them respect. Ecological consciousness makes possible the extension of an ethical attitude toward nature, pointing the way to a new relationship between nature and man. It is something that lies at the heart of humanity-it must develop almost as a matter of instinct

\section{HOLDEN'S ECOLOGICAL CONSCIOUSNESS}

What the concept of ecological consciousness suggests to us is that man should recognize that man is but one element in the ecology. This idea becomes a fundamental component in the contemporary environmental movement. Human beings tend to wait for destruction before any action is taken. Aldo Leopold emphasizes that we should be striving for harmony with the land and admitting at the outset that the thing we need must grow from within. Once humanity looks at organisms as individuals, having intrinsic value in them, we are more likely to show them respect. Ecological consciousness makes possible the extension of an ethical attitude toward nature, pointing the way to a new relationship between nature and man.

\section{A. The Catcher in the Rye}

The "Catcher in the Rye" makes its first appearance in chapter 16, when Holden admires a kid singing the poem Coming through the Rye by Robert Burns:

'It wasn't as cold as it was the day before, but the sun still wasn't out, and it wasn't too nice for walking. But there was one nice thing. This family that you could tell just came out of some church were walking right in front of me-a father, a mother, and a little kid about six years old...the kid was swell. He was walking in the street, instead of on the sidewalk, but right next to the curb. He was making out like he was walking a very straight line, the way kids do, and then the whole time he kept singing and humming. I got up closer so I could hear what he was singing. He was singing that song. 'If a body catch a body coming through the rye'...He kept on walking next to the curb and singing 'If a body catch a body coming through the rye.' It made me feel better .It made me feel not so depressed any more. (P115)

And it recurs in chapter 22, when Phoebe asks Holden what he wants with his life, he replies with his image again of a "catcher in the rye". He imagines a field of rye perched high on cliff, full of children romping and playing. He says he would like to protect the children from falling off the edge of the cliff by "catching" them if they were on the verge of tumbling over:

"I keep picturing all these little kids playing some game in this big field of rye and all. Thousands of little kids, and nobody's around--nobody big, I mean--except me. And I'm standing on the edge of some crazy cliff. What I have to do, I have to catch everybody if they start to go over the cliff--I mean if they're running and they don't look where they're going 1 have to come out from somewhere and catch them. That's all I'd do all day. I'd just be the catcher in the rye and all."'(P173)

Two meanings can be derived from Holden's dream: the first one is to "be in the rye". Definitely, rye symbolizes the nature which is peaceful, beautiful and unpolluted; Nature, as the purest and the holiest force on humans, is a symbol of human spirit. It is believed that humans can find good in nature. When one feels blended into nature and becomes one with nature, the soul of the individual is part of nature. As to Holden, nature is the media to seek for the divinity of humans, and an activator for humans to cultivate themselves and elevate themselves spiritually. Nature is in fact a helper for human perfection. Thus, although he grew up in a big city, Holden is always longing for leaving the skyscrapers and prosperity for the pure and fresh rye, which is the last Eden garden not destroyed by human beings. The second one is "to be a catcher". Just as his name indicates, he always tries to "catch" or "hold on" something, that is, innocent and natural nature of human beings. In a society where human relationships are marked by superficiality, and humans are measured in terms of social status and money income, to some extent, the frustrated, disillusioned boy succeeded in rebelling against the "phoniness" around him, striving for certain durable human goods - truth, freedom and love. Obviously, Holden's wish to stay in the rye and prevent the children from falling off the cliff is of profound symbolic significance. In addition to the symbolic meaning of rye, a group of children playing in the rye can be regarded as the symbol of a harmonious state between man and nature; children's falling off the cliff symbolizes that human beings are separated from nature, trapped in the mortal world and polluted by the worldly affairs. What Holden wants to do is to be the guardian of innocence and protector of innocents. Thus, we also can discern Salinger's implied creed-man, who is pure in his childhood, is not corrupted until he enters adult society. Besides, man in his early state is more harmonious with nature.

In a word, nature is highly symbolic to Holden. He saw a close association with nature as a means toward a fuller life. Living as naturally as possible and giving up those unnecessary material needs is one of the possible ways toward the perfection of life. It is the endless source for him to seek for the ultimate spiritual truths. By returning to nature and being in harmony with nature human beings can find a counteraction against the alienating power of commercialism. His distinctive identity of "the catcher in the rye" to catch and prevent kids from being hurt and killed is the typical 
embodiment of his ecological consciousness.

\section{B. The Return to Nature}

Besides Holden's dream, he cherished another romantic fantasy--fleeing far away to seek seclusion as an anonymous deaf-mute in an idyllic cabin near the woods. This kind of emotion can be conceived in the following passages:

"You're probably the only reason I'm in New York right now, or anywhere. If you weren't around, I'd probably be someplace way the hell off. In the woods or some goddam place."(P131) "They'd let me put gas and oil in their stupid cars, and they'd pay me a salary and all for it, and I'd build me a little cabin somewhere with the dough I made and live there for the rest of my life. I'd build it right near the woods ,but nor right in them, because I'd want it to be sunny as hell all the time .I'd cook all my own food , and later on, if I wanted to get married or something, I'd meet this beautiful girl that was also a deaf-mute and we'd get married. She'd come and live in my cabin with me, and if she wanted to say anything to me, she'd have to write it on a goddam piece of paper, like everybody else."(P 199)

Although born in cities, Holden is eager to leave the prosperity of New York for nature, in his pursuit of freedom and love. His enthusiasm for nature, in a way, indicates the spiritual healing value of nature - nature is people's spiritual sanctuary. When one is hurt in his heart, he can return to nature and find spiritual consolation. And if the one who is hurt returns to the embrace of nature heart and soul, he will feel relieved; all his troubles will completely vanish. Nature can sublimate one's sentiment, purify his heart and improve his morality. Throwing oneself into nature heart and soul, one can exist as a pure, natural, real being, and can reveal his true personality and feelings and can find his true self. This is the spiritual healing value of nature. Being a deaf-mute and recluse helps Holden to be alienated from the phony world and living in the woods helps him to embrace the nature.

As to the museum of natural history, Holden tells explicitly the symbolic meaning of the displays appealing to him because they are frozen and unchanging. He also mentions that he is distressed by the fact that he has changed every time he returns to them. The museum also represents the world Holden wishes he could live in: "it's the world of his "catcher in the rye" fantasy, a world where anything never changes, where everything is simple, understandable, and infinite."

\section{The Passion for Children-Image of Nature}

In addition to all those details showing Holden's obsession with "nature", the image of children is, undoubtedly, a key point among all the details in Holden's ecological consciousness.

Child is part of nature, which is the common conception in the history of the romantic literature toward nature. The innocence and goodness of children is one of the primary cultural heritages left by Rousseau for the later generation and it is also reflected in the romantic poets. It is the romantic poets that have first realized man is wandering and questing in the wrong way, so they have taken the motif of "returning to home" as their final purpose. And it is also among the possibilities of returning to home, children assume this important role: a bridge to nature.

Salinger holds the belief that the human animal is pure in his childhood and he is not corrupted until he enters society. And Salinger is not the first writer who openly declared the redemptive effect of the children's world. Wordsworth once wrote:

The child is father of the Man;

And I could wish my days to be

Bound each to each by natural piety.

"The child is father of the man", which seems contrary to the common practice, in essence it contains profound spiritual pursuit demonstrates the call by those alienated for the purest and most beautiful spiritualism. The spiritual trauma in the adult world and all the agonies can be purified and healed in the children's world. Holden, as an adolescent boy on the brink of adulthood, is extremely tired of the hypocrisy and degradation in modern society. What he's eager to do is to escape from a world of alienation and quests for self-identity, going back to nature and seeking a new place existing only in the children' innocent world. So children in The Catcher in the Rye such as Allie, Phoebe, and the kid humming the title song, play a role of beacon light in Holden's mind.

Though in the adult world Holden's quest for innocence and love ends in sheer desperation, his efforts receive an award in the children's world. It's children's natural and simple nature that offers him pleasure and solace in a phony world. In a phony world, his candid communication with children and his dream of childhood become the inevitable harbor for his turbulent heart.

To a certain degree, children's innocent and simple nature gives him warmth and strength. Holden' feeling towards children shows that he wants to recover the lost self as well as the lost paradise. The power of children in the novel is of great significance, as it is the foundation for Holden's self-redemption and the spiritual power of revival. And through children's intuitive power, Holden can obtain a more profound understanding of society. It is children who help Holden to be alienated from the phony world and embrace the nature.

\section{HARMONY}

\section{A. Harmony with Nature}

Resembling Leopold and Naess, everything in nature is a living being to Holden. Lagoon, situated in the Central Park, 
is endowed with life, power and character of purity in his mind. In Holden's eye, lagoon is no longer a common pond in New York. It is an epitome of the whole nature. What people do to lagoon is what they do to the whole nature. It is the image of purity. It feeds ducks and fishes in it, and transforms the purity into them.

Holden shows great concerns for other creatures. The matter of the Central Park ducks is to be forever in Holden's mind during his Christmas weekend in New York. Confused by where the ducks go in winter, he insists on figuring out their future. Besides asking the cabbies about them, he looks for them all around the Central Park lagoon in the midnight. He assumes his responsibility to care for, save and protect those helpless creatures.

The ducks live in the pond that belongs to part of nature, and the nature has great power to protect or take care of the lives, as the cabdriver says: "if you was a fish, Mother Nature would take care of you, wouldn't she?"(P83)

Holden wishes to set up a harmonious relationship with the animals and plants at the Central Park. He knows the movement of each kind of animal in four seasons; and believes that animals exist for their own sake. Humans and animals are all part of nature. One should not be over the other. Nature does not exist without animals; ducks and fish are not only wild creatures, but also part of mountains and rivers, part of nature.

\section{B. Harmony between Humans and Nature}

Since the very advent of human civilization, with conqueror's might and pride, man has exerted great influence on nature. Meanwhile, the civilized society has also imparted bondage and depression to man. Under the yoke of civilization, man has forever cherished a passionate yearning for returning to nature and recapturing the lost heaven. Such tendency of going back to nature, though it changes with times, has been an eternal theme in every culture. Generally, the tendency of going back to nature reveals passive escape from society, so it is often compulsory, passive, and with a touch of guilty consciousness. Being tortured to the verge of breakdown by modern civilization, Holden is compelled to quest for the West for a spiritual asylum in spite of his longing for nature. In history, the West was the habitat for those who were not fit for society.

"With its wider hospitality to the values of rugged individuality, self-reliance, and boundless freedom, the West has a deep, mythic appeal."

"We'11 stay in these cabin camps and stuff like that till the dough runs out. Then, when the dough runs out, I could get a job somewhere and we could live somewhere with a brook and all, and, later on, we could get married or something. I could chop all our own wood in the winter-time and all. Honest to God, we could have a terrific time!'”(P132)

Holden's expectation shows he is a descendant of American Transcendentalists'. Holden's vision of the idyllic life bears more than a few resemblances to the one Thoreau outlines in Walden. For Holden, nature is a spiritual haven. In desolate and uninhabited woods, at least he can virtually escape from phony society, achieve benefit to his traumatic psychology tranquility and inhale clean air. And those will be of great and declining vigor. Unconsciously he tells a fact-being far from civilization, nature has become a spiritual heaven. What's more, one can only behave to his principles and attain a kind of pure, natural and true existence in nature. He may make a living out of honest work exempted from all kinds of fraud and hypocrisy. In a civilized society, it is impossible for one to behave decently all the time, as one must pursue money. In contrast, chopping in nature can not only ensure him an honest living but also the perfection of his soul. In nature, he can totally escape from the bondage of ethics, tradition and religion, thus he may regain vigor and sound mind. In some philosophers' view, man and nature are harmonious entity. It's self-evident that Holden's going back to nature is to establish a completely idyllic world, that's to say, the pursuit of ideals and beliefs. Indeed, in nature man can discover the essence of life and spiritual values.

Holden's constant concern with ducks also implies that he has an unswerving tendency towards nature. His escape, I $\mathrm{n}$ a sense, is the quest for spiritual perfection and enlightenment. And his going back to nature, in consequence, is an active return. Though he cannot really retreat to nature, this dream really helps him cherish such a quest with all his enthusiasm and belief. He really can enjoy matchless happiness and consolation. Moreover, if he abandons modern life and goes back to nature, nature will take care of him. In his eyes, in nature, everything is true, so it can provide humans with freedom and tranquility. Modern civilization has spread to the remotest corner, thus he finds in the real world no sanctuary, no place to escape. He has no final destination. Nevertheless, his quest for nature, to a certain degree, soothes him and helps him regain a sound soul.

Nature does not belong to humans. On the contrary, according to the ecologists, humans are part of nature; humans are just particles in the circle of the ecosphere. This circle may go on functioning without humans as it once did. However, humans cannot go on living beyond this circle. Holden is strongly conscious of his oneness with nature. The sense of sympathy between humans and nature is vividly expressed as follows:

He looks down upon people who love cars, and he himself prefers horses:

“Take cars, I said it in this very quiet voice. Take most people, they're crazy about cars. They worry if they get a little scratch on them, and they're always talking about how many miles they get to a gallon, and if they get a brand-new car already they start thinking about trading it in for one that's even newer. I don't even like old cars. I mean they don't even interest me. I'd rather have a goddam horse. A horse is at least human, for God's sake."(P130)

Comparing cars with horses, Holden obviously rejects the modern industrial society, yearning for primitive and peaceful world. It can be concluded that Holden's choice of horse represents his ecological consciousness. 


\section{CONCLUSION}

The Catcher in the Rye is concerned with human society and nature. It urges us to understand that nature is the headstream of human lives, the root of human foothold and the basis of our emotions. From the perspective of social significance, The Catcher in the Rye awakens us into thinking over such questions: how can humans and nature, civilization and environment both survive? As for individuals, how can we achieve a more meaningful and wiser life? Confronting the present global ecological crisis and alienation of human civilization, human civilization should move on to a higher-level eco-civilization. From the perspective of the whole ecological benefit, we are supposed to take the ecological responsibility, to respect the values and rights of all forms of life and to greatly enrich our spiritual lives. Only in this way will human being live more harmoniously with nature in the future.

\section{REFERENCES}

[1] Salinger, J.D. (1951). The Catcher in the Rye. Boston: Little, Brown, and Company, Inc.

[2] Mazel ,David. (2001). A Century of Early Ecocriticism. Athens and London: The University of Georgia Press.

[3] Aldo, Leopold. (1987).A Sand County Almanac, and Sketches Here and There. New York: Oxford University Press.

[4] Harold, Bloom. (1987). Modern Critical Views: J.D. Salinger. Chelsea House Publishers.

[5] Pinsker, Sanford. (1993). The Catcher in the Rye Innocence Under Pressure. New York: Twayne Publishers.

[6] Worster, Donald. (1993). The Wealth of Nature: Environmental History and the Ecological Imagination. New York: Oxford University Press.

[7] Xuesheng,Yuan. (2004). Returning to Youth and nature - The catcher in the Rye in Ecocriticism. Journal of Nanchang University (humanities and social sciences) vol.35. No.3.

[8] Jieming, Zhang. (2002). Permanent Mystery: Yearning for Nature -The Catcher in the Rye. Journal of Xiangtan University (Philosophy and Social Sciences) vol.26. No.3.

[9] Garrard, Greg. (2004). Ecocriticism. London: Routledge.

[10] Glotfelty, Cheryll and Fromm. (1996). Harold(eds).The Ecocriticism Reader: Landmarks in Literary Ecology. Athens: The University of Georgia Press.

Cui Wang was born in Qingdao, China in 1981. She will receive her M.A degree in American Literature from Liaocheng University, Shandong Province, China in 2010.

She is currently an English teacher in De Zhou University, China. Her research interests include English language and American literature.

Xiaofen Zhang was born in Dezhou, China in 1963. She received her B.A. degree in ELT (English language teaching) from Liaocheng University, Shandong Province, China in 1996.

She is currently an associate professor in De Zhou University, China. Her research interests include English language and American literature. 